\title{
Peran Masyarakat dalam Mencapai Pola Konsumsi Berkelanjutan
}

\author{
Meri Enita Puspita Sari \\ Program Studi Ilmu Pemerintahan Fakultas Ilmu Sosial dan Ilmu Politik \\ Universitas Riau Kepulauan, Batam Indonesia \\ puspita.meri@yahoo.co.id
}

\begin{abstract}
In this study, the authors discussed in the pattern of sustainable consumption for consumer health and environmentally friendly so as to achieve human goals can survive to live on earth until his offspring through sustainable consumption patterns and sustainable living. This can be achieved through the government's way of promoting sustainable consumption patterns, through education that can increase the bargaining power of consumers, provide access to consumers on non-hazardous products, promote fair, equitable and sustainable development in economic and social development and information services and options information needs in accordance with the wishes and needs of individuals. Continuous consumption is a requirement of consumers to meet the needs that are needed and ensure the fulfillment of its needs it does not endanger the environment. This awareness emerged, when already many of consumers who enjoy education from various disciplines, awareness of the fulfillment of needs in accordance with the needs arise. Consumers also begin to feel the advantages of a result of business, because many consumers who suffered losses both in terms of health and from existing consumers imbalances of the earth over all goods used so far are not safe against the environment.
\end{abstract}

Keywords: role of society, consumption sustainable, consumer

\begin{abstract}
Abstrak
Pada penelitian ini, yang penulis bahas ialah mengenai pola konsumsi yang berkelanjutan yang aman bagi kesehatan konsumen serta ramah lingkungan sehingga dapat mencapai tujuan manusia dapat bertahan tinggal di bumi hingga anak cucunya melalui pola konsumsi berkelanjutan dan kehidupan yang berkelanjutan. Hal ini dapat dicapai melalui bagaimana pemerintah dalam melakukan promosi pola konsumsi berkelanjutan, yakni melalui pendidikan yang dapat meningkatkan daya tawar konsumen, memberikan akses padakonsumen atas produk non berbahaya, melakukan promosi yang adil, merata dan berkelanjutan dalam pembangunan ekonomi dan sosial dan perlindungan lingkungan dengan memberikan informasi serta kemudahan atas akses informasi yang memadai untuk memungkinkan konsumen membuat pilihan informasi sesuai dengan keinginan dankebutuhan individu. Konsumsi berkelanjutan ialah kesadaran konsumen untuk memenuhi kebutuhan yang sesuai dengan yang dibutuhkan dan menjamin pemenuhan kebutuhannya itu tidak membahayakan lingkungan. Kesadaran ini muncul, ketika sudah mulai banyak dari konsumen yang menikmati pendidikan dari berbagai disiplin ilmu, kesadaran akan pemenuhan kebutuhan yang sesuai dengan kebutuhan pun muncul. Konsumen juga mulai merasakan betapa telah menjadi objek dari usaha produsen, sebab banyak konsumen yang mengalami kerugian baik dari segi kesehatan maupun dari konsumen yang sudah menyadari ketidakseimbangan bumi atas segala barang yang digunakan selama ini tidak aman terhadap lingkungan.
\end{abstract}

Kata Kunci : peran masyarakat, konsumsi berkelanjutan, konumen

\section{PENDAHULUAN}

Dilihat dari perkembangan sejarah, pola konsumsi pada diri manusia sudah ada sejak lahirnya. Sifat konsumsi yang ada pada diri manusia selalu mengalami perkembangan, hal ini semakin meningkat sejak terjadinya pergesaran masyarakat, yaitu dari masyarakat 
agraris menuju masyarakat modern dan sekarang menjadi masyarakat global. Perubahan ini diawali dari lahirnya industri-industri yang mulai menggunakan mesin, mesin merupakan penemuan baru dibidang teknologi yang dapat mempermudah cara kerja dan meningkatkan hasil produksi barang yang dibutuhkan manusia yang sebelumnya dibuat manusia dengan menggunakan tangan dan teknologi sederhana. Perubahan-perubahan tersebut membawa dampak bagi pengelolaan sumber daya alam yang ada di bumi, baik yang di darat atau di laut, karena bahan-bahan yang diproduksi berasal dari sumber daya alam.

Sumber daya alam (SDA) adalah sesuatu yang dapat dimanfaatkan untuk berbagai kepentingan dan kebutuhan hidup manusia agar hidup lebih sejahtera yang ada di sekitar alam lingkungan hidup kita. Sumber daya alam bisa terdapat di mana saja seperti di dalam tanah, air, permukaan tanah, udara, dan lain sebagainya. Oleh karena itu, pelestarian potensi sumber daya alam sangat diperlukan untuk kebutuhan kehidupan orang banyak. Manusia dalam kehidupan sehari-hari selalu membutuhkan makanan sebagai kebutuhan primer dan pakaian sebagai kebetuhan sekunder, dan kebutuhan itu yang selalu harus terpenuhi karena merupkan kebutuhan dasar dan masuk dalam konsumsi berkelanjutan masyarakat.

Sumber Daya Alam (SDA) dipelihara, diolah dan dimanfaatkan oleh masyarakat untuk keberlanjutan hidup oleh karena itu butuh peran serta masyarakat dalam pelestarian Sumber Daya Alam (SDA) semaksimal mungkin. Adapun Peran menurut Soekanto adalah proses dinamis kedudukan (status). Apabila seseorang melaksanakan hak dan kewajibannya sesuai dengan kedudukannya, dia menjalankan suatu peranan. Perbedaan antara kedudukan dengan peranan adalah untuk kepentingan ilmu pengetahuan. Keduanya tidak dapat dipisahpisahkan karena yang satu tergantung pada yang lain dan sebaliknya.

Begitu tergantungnya manusia dengan sumber daya alam (SDA) sehingga masyarakat harus pintar dalam pemanfaatan sumber daya alam, masyarakat tidak hanya boleh memanfaatkan sumber daya alam yang ada untuk kebutuhan sehari-hari secukupnya saja, karena pelestarian sumber daya alam sangat menentukan nasib generasi penerus yang juga membutuhkan hal yang serupa.

Untuk merespon perubahan iklim global, telah ada pengakuan kesepakatan forum internasional antar pemerintahan dalam perubahan iklim melalui UNFCCC (United Nations Framework Convention on Climate Change). Terdapat 17 target arah tujuan pembangunan berkelanjutan, dimana target ke-12 adalah memastikan pola produksi dan konsumsi berkelanjutan. Menerapkan berbagai kerangka program 10 tahun produksi dan konsumsi berkelanjutan, seluruh negara harus mengambil aksi dengan dipimpin oleh negara negara 
berkembang, dengan mempertimbangkan tingkat pembangunan dan kemampuan negaranegara berkembang. Pada tahun 2030 telah ada pencapaian tata kelola berkelanjutan dan efisiensi penggunaan sumber daya yang alami dan ramah lingkungan.

Menurut data PBB pada tahun 2007 akan terdapat populasi penduduk perkotaan sebesar 3,5 milyar jiwa dari total 7 miliar jiwa penduduk dunia. Pada tahun 2050 diperkirakan meningkat menjadi 6 milyar jiwa dari total 8,5 milyar jiwa. Sekitar 80\% PDB global dihasilkan oleh masyarakat perkotaan, dimana wilayah perkotaan hanya menempati $2 \%$ total luas lahan dunia. Penduduk perkotaan di Indonesia pada tahun ini diperkirakan 125 juta jiwa dari total populasi sekitar 250 juta jiwa. Diproyeksikan akan terjadi peningkatan pada tahun 2030 hampir mendekati 200 juta jiwa dari total populasi yang mendekati 300 juta jiwa. Pertumbuhan pesat wilayah perkotaan akan sangat mempengaruhi penggunaan sumber daya, dimana akhirnya akan memberikan perubahan sosial dan dampak lingkungan masyarakatnya. Penggunaan sumber daya (flow resources) seperti air, kertas dan plastik, sangat dipengaruhi oleh gaya hidup masyarakatnya. Tiongkok dan Indonesia merupakan dua negara penyumbang limbah plastik terbesar di lautan. Dari citra satelit akan terlihat kumpulan sampah di laut lepas seperti pulau-pulau baru. Limbah ini meliputi limbah botol, kantong plastik serta zat-zat sisa makhluk hidup lainnya. Produksi plastik menghabiskan dua belas juta barel minyak bumi atau setara dengan 11 trilyun rupiah. Penggunaan kantong plastik rata-rata per orang Indonesia sekitar 700 lembar/tahun, dimana dalam sehari mencapai 4000 ton dengan perkiraan konsumsi 100 milyar kantong per tahun. Padahal plastik memiliki sifat sulit terdegradasi dan akan membutuhkan waktu ratusan hingga ribuan tahun untuk dapat terurai (terdekomposisi) dengan sempurna. Beberapa faktor yang sangat mempengaruhinya antara lain pola konsumsi individu dan organisasi baik pemerintahan maupun swasta. Perilaku agen ekonomi seperti kalangan bisnis, konsumen dan masyarakat. Kemudian sifat partisipasi pemangku kepentingan dalam pengambilan keputusan. Lalu sistem infrastruktur (baik 'lunak' maupun 'keras') dan teknologi. Beberapa contoh pola konsumsi yang menjadi perhatian adalah pembuangan sampah oleh individu, membeli baju baru dan gadget baru setiap minggu, penggunaan tisu toilet sampai 7 lapis padahal cukup 1 lapis saja. Angkutan bus berAC, berkursi lebar dengan hanya 12 penumpang, menjadikan eksklusif demi kepuasan. Berlebihannya makanan dan minuman dalam penyelenggaraan seminar/pameran, tentu saja akan menimbulkan pembuangan yang percuma. Dalam wilayah perkotaan akan terjadi interaksi alami antar masyarakat dalam lingkungan sekitarnya. Sementara interaksi buatan 
akan terlihat pada sebuah pasar dimana sebagai fasilitas publik tempat berkumpulnya transaksi perekonomian.

\section{KONSUMSI BERKELANJUTAN}

Konsumsi berkelanjutan yang jarang kita dengar dalam kehidupan sehari-hari, beda halnya dengan istilah-istilah lingkungan seperti perubahan iklim (climate change) ataupun pemanasan global (global warming). Padahal, konsumsi berkelanjutan sudah banyak diperbincangkan dalam lingkup gerakan konsumen sejak belasan tahun yang lalu. Berawal dari KTT Bumi di Rio de Janero, Brazil tahun 1992, penggerak konsumen menyadari bahwa pembangunan berkelanjutan, sustainable development, tidak dapat berjalan tanpa perubahan pola konsumsi masyarakat. Jadilah konsep sustainable consumption ditambahkan dalam $U N$ Guidelines for Consumer Protection (Panduan PBB untuk Perlindungan Konsumen) pada 1999 untuk melengkapi rujukan perlindungan konsumen yang telah diakui PBB sejak 1985 ini.

Konsumsi berkelanjutan atau disebut juga sustainable consumption merupakan suatu pola konsumsi barang dan jasa yang tidak memberikan dampak negatif terhadap lingkungan guna memenuhi kebutuhan dasar manusia. Defra (2003) menjelaskan bahwa:

Sustainable consumption is rising up the environmental policy menu, as a strategy to achieve more sustainable development which requires widespread changes in behaviour at all levels of society to reduce the environmental impacts of consumption (Gill Seyfang, 2007: 120).

Konsumsi berkelanjutan adalah hasil dari suatu proses pengambilan keputusan dari konsumen sebagai tanggung jawab terhadap terhadap lingkungan sesuai dengan kebutuhan. Menerapkan konsumsi berkelanjutan berarti menjadi seorang konsumen yang beretika, yaitu merasa bertanggung jawab terhadap isu-isu sosial dan lingkungan di dunia dan melawan masalah ini dengan pola perilaku sendiri.

Konsumsi Berkelanjutan merupakan penggunaan produk dan jasa untuk memenuhi kebutuhan dasar dan menuju kualitas hidup yang lebih baik, dengan meminimalkan penggunaan sumber daya alam, bahan kimia serta pembuangan sampah dan polutan sehingga tidak membahayakan kebutuhan generasi mendatang.

Di Indonesia, sebagai contoh di Kota Batam, yang merupakan kota yang sedang berkembang, merupakan salah satu kota industri yang ada di Indonesia, begitu banyak ragam masyarakat, dari penduduk asli sampai dengan penduduk pendatang yang berasal dari luar kota batam bahkan berasal dari luar negeri karena mengingat Kota batam yang memiliki 
posisi strategis yang berada diantara perbatasan Singapura dan Malaysia. Masyarakat Kota Batam tergolong masyarakat yang sudah maju, sebagian termasuk dalam kelompok menengah atas dan memiliki pola konsumsi berlebihan. Hal tersebut terjadi dikarenakan kondisi dan kemampuan ekonominya yang dapat mengonsumsi apa saja dan dalam jumlah berapapun. Bagi kelompok ini, perubahan pola konsumsi yang diharapkan adalah mengurangi jumlah konsumsi. Namun di sisi lain, sebagian besar penduduk terutama penduduk asli yang berada dipulau-pulau kecil Kota Batam. Bagi mereka, jangankan mengurangi konsumsi, kebutuhan dasar pun belum terpenuhi. Prinsip konsumsi berkelanjutan harus memastikan setiap warga negara, setiap penduduk harus terpenuhi kebutuhan dasarnya. Kelompok yang kurang beruntung ini justru harus ditingkatkan konsumsinya. Akses terhadap kebutuhan dasar seperti pangan, juga energi harus dipastikan dapat diperoleh. Tetapi tentu saja tidak dengan cara-cara yang menguras sumber daya alam dan merusak bumi . Tidak mengulangi kesalahan yang pernah dilakukan sebelumnya.

Dalam berkonsumsi, konsumen cenderung menginginkan kemudahan dan kepraktisan, serta kenyamanan. Inilah yang tengah dinikmati oleh kelompok menengah tadi. Memiliki kendaraan sendiri, kenyamanan rumah berpendingin, menikmati makan di luar rumah dan berbagai kepraktisan lain yang membanggakan. Perkembangan kelompok menengah di Kota batam cukup pesat karena juga disebabkan oleh kemudahan-kemudahan dalam proses mendapatkan kebutuhan diluar dari kebutuhan dasar masyarakat. Tidak heran bila kelompok inilah yang menjadi sasaran kampanye untuk mengubah pola konsumsi.

Ide perubahan pola konsumsi mungkin mengkhawatirkan sebagian orang karena beranggapan harus meninggalkan berbagai kemudahan dan kenyamanan yang tengah dinikmati. Berarti mengurangi kualitas hidup dan menempatkan diri ke masa lalu. Misalnya harus bersusah payah mengejar angkutan umum, berkeringat karena tidak menggunakan pendingin ruangan, atau lainnya.

Menerapkan pola konsumsi berkelanjutan tidak berarti harus meninggalkan berbagai kemudahan dan kenyamanan tersebut. Lantas, apa yang membedakannya dari pola-pola yang konvensional? Memahami prinsip-prinsip konsumsi berkelanjutan sebenarnya sederhana. Penerapannya yang mungkin dirasakan tidak mudah. Beberapa prinsip dasar adalah: (1) memahami apa yang kita konsumsi, (2) memahami dampak konsumsi terhadap lingkungan dan keselamatan bumi, (3) memahami dampak konsumsi terhadap masyarakat lain, (4) memahami dampaknya terhadap neraca perdagangan, perekonomian nasional dan industri lokal. 
1. Memahami apa yang kita Konsumsi

Apa yang kita beli dan konsumsi seringkali tidak dipikirkan secara mendalam. Karakter konsumen secara umum adalah sulit membedakan antara belanja produk-produk yang hanya memenuhi keinginan semata, atau membeli barang yang benar-benar sedang dibutuhkan. Terkadang masyarakat hanya membeli barang atas dasar mengkoleksi atau gengsi demi tercapainya gaya hidup yang tinggi.

Pemahaman dengan produk yang di konsumsi harus dimiliki oleh semua masyarakatT, masyarakat harus tahu produk yang ramah lingkungan atau tidak. Diperlukan pengetahuan yang cukup serta ketersediaan informasi yang memadai dan akurat. Dalam memilih produk, periksalah kandungannya. Atau apakah untuk memproduksinya memerlukan bahan-bahan kimia yang kemudian dilepas dan menghasilkan limbah berbahaya dan mengancam lingkungan. Atau dari produknya sendiri, menyebabkan sampah yang akan menjadi beban bumi.

2. memahami dampak konsumsi terhadap lingkungan dan keselamatan bumi

Konsumsi berkelanjutan sama dengan kepedulian kita pada generasi mendatang. Pola konsumsi kita jangan sampai hanya menggerus sumber daya alam dan membuang segala rupa sampah ke bumi. Generasi penerus juga memiliki hak untuk meraskan kenikmatan sumber daya alam karena kemajuan teknologi tidak akan mampu mengatasi keserakahan penduduk bumi. Seperti kata Mahatma Gandhi yaitu bumi cukup untuk memenuhi kebutuhan hidup seluruh manusia, tetapi tidak akan mampu memenuhi keinginan seseorang atau segelintir manusia yang serakah. intinya berkonsumsi secara efisien, secukupnya, tidak boros dan berlebihan, tanpa harus kehilangan kenyamanan, kemudahan, dan mundur ke pola-pola masa lalu.

Konsumsi Berkelanjutan adalah penggunaan barang dan jasa untuk merespon kebutuhan dasar dan memenuhi syarat kehidupan, dengan cara meminimalkan penggunaan sumber daya alam, bahan beracun, dan emisi limbah dan polutan selama siklus hidup, sehingga tidak membahayakan kebutuhan generasi mendatang ( Symposium Sustainable Consumption. Oslo, Norway; 19-20 January 1994).

World Business Council for Sustainable Development (WBCSD) mencatat beberapa hal yang menjadi tantangan pembangunan berkelanjutan, dimana sektor bisnis dapat membantu mengembangkan tingkat yang lebih berkelanjutan dan pola konsumsi. Dari sisi kompetisi kesempatan ini bagi sektor bisnis membantu konsumen memilih dan menggunakan barang-barang mereka dan layanan secara berkelanjutan. Untuk melakukannya, bisnis harus 
menciptakan nilai yang berkelanjutan bagi konsumen dengan menyediakan produk dan layanan yang memenuhi fungsional mereka dan kebutuhan emosional - sekarang dan untuk generasi mendatang - sementara menghormati batas lingkungan dan nilai-nilai bersama.

Beberapa isu yang menjadi tantangan bagi sektor bisnis adalah:

1. Pendorong Konsumsi Global

1. Pertumbuhan cepat populasi global - Penduduk 9 miliar diharapkan pada tahun 2050

2. Kenaikan kemakmuran global dan terkait konsumsi - kelas menengah global diperkirakan tiga kali lipat pada tahun 2030;

3. Konsumen berpenghasilan rendah merupakan pasar dari US \$ 5.000.000.000.000

4. Budaya "konsumerisme" di antara kelompok pendapatan yang lebih tinggi, yang jumlahnya terbesar dari sisi pendapatan per kapita global

2. Pola konsumsi global \& dampaknya

1. Ekosistem Bumi - 60\% dari jasa ekosistem bumi telah terdegradasi dalam 50 tahun terakhir.

2. Pasokan energi dan bahan sumber daya yang dibutuhkan untuk pertumbuhan industri konsumsi sumber daya alam diperkirakan meningkat hingga 170\% dari bio-kapasitas bumi tahun 2040

3. Sistem sosial manusia dan kesejahteraan - Kesejahteraan manusia tidak selalu bergantung pada tingginya tingkat konsumsi

3. Peran konsumen

1. Konsumen semakin khawatir tentang isu-isu lingkungan, sosial dan ekonomi, dan semakin bersedia untuk bertindak atas kekhawatiran mereka

2. Kesediaan Konsumen sering tidak diterjemahkan ke dalam perilaku konsumen yang berkelanjutan karena berbagai faktor -seperti;

a.ketersediaan,

b.keterjangkauan,

c.kemudahan,

d.kinerja produk

e.prioritas yang saling bertentangan,

f.skeptisisme dan,

g. kekuatan kebiasaan

4. Peran bisnis 
Pengaruh utama konsumsi berkelanjutan. Kasus bisnis: Bisnis pendekatan untuk konsumsi berkelanjutan dapat dikelompokkan menjadi tiga kategori:

1. Inovasi - proses bisnis dalam pengembangan produk baru dan peningkatan layanan dan pergeseran bisnis untuk menggabungkan ketentuan yang disepakati yaitu memaksimalkan nilai sosial dan meminimalkan biaya lingkungan sebagai 'raison d'etre bisnis' (bottom line)

2. Pilihan memengaruhi - penggunaan pemasaran dan kampanye peningkatan kesadaran untuk mengaktifkan dan mendorong konsumen untuk memilih dan menggunakan produk yang lebih efisien dan berkelanjutan.

3. Pilihan penyuntingan - penghapusan "tidak berkelanjutan" produk dan jasa dari pasar dalam kemitraan dengan aktor lain dalam masyarakat.

\section{PERAN MASYARAKAT TERHADAP KONSUMSI BERKELANJUTAN}

Dalam beberapa tahun terakhir, isu-isu lingkungan telah menerima banyak perhatian, mencerminkan meningkatnya perhatian publik dan kesadaran masalah lingkungan. Kampanye berbagai kelompok lingkungan telah menyebarkan pengetahuan dan kesadaran masalah lingkungan. Liputan media pada isu-isu lingkungan telah meningkat secara dramatis. Lingkungan kebijakan juga banyak dipengaruhi oleh protokol internasional, seperti kesepakatan yang dibangun dalam serial Konferensi Tingkat Tinggi (KTT) Bumi.

Ada bukti bahwa sebagian besar pasar Barat telah dipengaruhi oleh perilaku konsumen hijau, yang berarti perilaku yang mencerminkan kepedulian tentang efek dari manufaktur dan konsumsi pada lingkungan alam. Selain perubahan hukum, selama dekade terakhir banyak perusahaan mulai merasakan dampak dari kekuatan pasar, konsumen telah berubah dari tidak peduli menjadi lebih peduli terhdap lingkungan. Bahkan sekarang, konsumen sering memboikot perilaku yang dihasilkan produsen berdasarkan pelaporan media dan aktivitas kelompok penekan.

Penggunaan mesin dalam dunia industri sangat membantu pemenuhan kebutuhan manusia, dimana barang yang dibutuhkan semakin cepat selesainya dibandingkan denganteknologi sederhana sebelumnya, harganya juga lebih terjangkau sehingga hampir dapatdinikmati oleh masyarakat dari berbagai kalangan, serta jumlah produksi mengalami peningkatan yang pesat. Hal ini memacu pola konsumsi manusia meningkat, produsensebagai penyedia barang termotivasi menggali ide-ide cemerlang, guna memenuhi kebutuhan manusia yang semakin meningkat. Hal ini mengakibatkan manusia tidak lagi berbelanja atasdasar kebutuhan dasar saja, melainkan atas dasar keinginan, segala sesuatu 
yang diproduksidan menarik manusia itu akan dibeli, hal ini mengakibatkan sifat konsumtif manusia yang dipermainkan oleh produsen. Sifat konsumtif tersebut memacu produsen dalam berinovasi, menghasilkan barang-barang yang menarik konsumen, bahkan dengan harga yang tinggi sekalipun, sehingga di jaman modern ini tidak semua barang dapat dinikmati oleh semua kalangan khsusnya terhadap barang yang tergolong mewah. Hal ini menciptakan kesenjangan antara konsumen. Hal-hal tersebut di atas menjadikan kedudukan konsumen lemah. Sebelum adanya perubahan dari masyarakat agraris ke masyarakat industri antara konsumen dan produsen memiliki kesamaan kedudukan, namun setelah perubahan, terjadi ketidaksamaan daya tawar antar kedua belah pihak, dimana kedudukan produsen lebih tinggi dibandingkan dengan konsumen. Bahkan pelemahan konsumen semakin "jadi” ketika manusia memasuki era modern dan hingga kini globalisasi. Kemajuan ilmu pengetahuan dan teknologi menjadikandunia seolah tanpa batas, yang menjadikan timbulnya pasar bebas / perdagangan bebas. Tidak hanya sebatas perdagangan bebas, namun berbagai persaingan usaha juga muncul, bahkan praktik persaingan tidak sehat yang merugikan konsumen juga. Konsumen menjadi "obyek" atas praktik persaingan tidak sehat dan merugikan konsumen, dikarenakan informasi terbatas dan menyesatkan, daya tawar tidak ada, akses kesumbersumber daya ekonomi terbatas, lemahnya pendidikan/pengetahuan. Tidak ada pertimbangan bagi kesehatan konsumen dan keberlangsungan konsumsi serta keamananl ingkungan (keberlangsungan bagi kehidupan yang akan datang. Hal-hal inilah yang menarik perhatian dari berbagai kalangan yang memperhatikan betapa konsumen dirugikan sebablemahnya hukum sebagai alat perlindungan masyarakat dan menjadi perhatian dari kalangan pemerhati lingkungan hidup.

Dirasakan bahwa ekspolitasi sumber daya alam secara berlebihan diramalkan membawa dampak yang buruk bagi bumi yang ditinggali, yang menjadi perhatian saat ini adalah manusia sudah menaklukkan alam guna pemenuhan kebutuhan manusia itu sendiri, namun ratusan, ribuan atau bahkan jutaan orang masih berkubang dalam kemiskinan dan hidup dengan kualitas yang tidak menyenangkan. Masih ada orang yang tidak mampu mendapatkan makanan yang cukup untuk menunjang kehidupan berkaryanya.Seorang produsen, tidak memikirkan dari mana bahan yang dipakai guna menghasilkan suatu barang dan tidak juga memikirkan apa dampak kedepannya jika menggunakan bahan tersebut secara berlebihan, bahkan juga tidak mempunyai rancangan atas limbah industri yang dialirkan begitu saja keberbagai wilayah seperti lautan dan sungai, tanpa adanya pertimbangan atas gangguan ekosistem yang ada di wilayah tersebut, serta penggunaan energi dalam proses 
produksi tidak diperhatikan apakah pelepasan sisa energi dapat mengganggu kestabilan lingkungan, serta tidak juga memperhatikan bahan yang digunakan dalam barang hasil produksi apakah ramah lingkungan dan aman bagi kesehatan konsumen, yang ada pada diri seorang produsen ialah bagaimana memperoleh keuntunganyang besar dan bagaimana dapat memenuhi kebutuhan konsumen secara cepat danmemuaskan, tanpa memperhatikan dampak kedepannya.

Produksi yang tinggi dapat menyebabkan eksploitasi terhadap Sumber Daya Alam yang berlebihan, berdampak pada rusaknya lingkungan, seperti : menipisnya lapisan ozon, meningkatnya perubahan iklim, penurunan kualitas tanah, rusaknya areal hutan, terbatasnya sumber air, menurunnya sumber energi, polusi udara dan erosi. Hal ini merupakan ancaman yang bersifat mendunia. Mengingat manusia adalah mahluk yang hidup dalam siklus kehidupan denga alam,ahli memprediksikan dengan kondisi tersebut di atas maka dimasa yang akan datang akan terjadi kekacauan dimana minyak bumi dan batubara habis serta cadangan makanan dan air (SDA) tidak bisa lagi memenuhi kebutuhan semua orang.

Peradaban kita menghadapi risiko tersebut karena kesalahan kita selama ini telah menggunakan SDA secara salah dan mengganggu sistem yang alami, yakni telah memaksa bumi sampai kebatas kemampuannya. Kemampuan bumi untuk mendukung kehidupan manusia dan kehidupan lain telah berkurang sekali. Terlah terjadi juga kesenjangan bagi konsumen khususnya di negara berkembang, yakni ketidakseimbangan dalam hal ekonomi,hal ini mempengaruhi daya konsumsinya, ketidakseimbangan ini juga dapat mempengaruhi perilaku masyarakat pada umumnya bagi masyarakat menengah ke bawah dimana kesenjangan perekonomian dapat menciptakan tindakan kriminal yang tidak mengherankan dapat mengancam perdamaian dan kemantapan suatu negara.

Pada penelitian ini, yang penulis bahas ialah mengenai pola konsumsi yang berkelanjutan yang aman bagi kesehatan konsumen serta ramah lingkungan sehingga dapat mencapai tujuan manusia dapat bertahan tinggal di bumi hingga anak cucunya melalui polakonsumsi berkelanjutan dan kehidupan yang berkelanjutan. Hal ini dapat dicapai melalui bagaimana pemerintah dalam melakukan promosi pola konsumsi berkelanjutan, yakni melalui pendidikan yang dapat meningkatkan daya tawar konsumen, memberikan akses padakonsumen atas produk non berbahaya, melakukan promosi yang adil, merata dan berkelanjutan dalam pembangunan ekonomi dan sosial dan perlindungan lingkungan dengan memberikan informasi serta kemudahan atas akses informasi yang memadai 
untuk memungkinkan konsumen membuat pilihan informasi sesuai dengan keinginan dankebutuhan individu.

Konsumsi berkelanjutan ialah kesadaran konsumen untuk memenuhi kebutuhan yang sesuai dengan yang dibutuhkan dan menjamin pemenuhan kebutuhannya itu tidak membahayakan lingkungan. Kesadaran ini muncul, ketika sudah mulai banyak dari konsumen yang menikmati pendidikan dari berbagai disiplin ilmu, kesadaran akan pemenuhan kebutuhan yang sesuai dengan kebutuhan pun muncul. Konsumen juga mulai merasakan betapa telah menjadi objek dari usaha produsen, sebab banyak konsumen yang mengalami kerugian baik dari segi kesehatan maupun dari konsumen yang sudah menyadari ketidakseimbangan bumi atas segala barang yang digunakan selama ini tidak aman terhadap lingkungan. Sebagai contoh masyarakat industri produksi menggunakan energi sebagai penggerak, bahkan pemakaian energi dan bahan bakar ini menjadi semakin canggih. Konsumsi energi komersial tumbuh dengan laju yang terus meningkat. Konsumsi ini juga menimbulkan dampak serius pada lingkungan, dalam bentuk aliran asam, emisi metana dan limbah tambang lain; tumpahan minyak dari instalasi pantai dan lepas pantai serta dari kapal dan pencemaran udara oleh sulfur dioksida, nitrogen oksida dan karbondioksida ketika batu bara, minyak atau gas dibakar, industri-industri energi merupakan pelahap utama sumber daya yang tidak dapat diperbaharui dan sebagian akan meningkat harganya sebagai pemasok industri kimia.

Penggunaan energi komersial dan pemakaian produk-produknya menghasilkan limbah dalam jumlah besar. Sebagai contoh produknya ialah sistem pemanas/ pendingin listrik menggunakan high-grade heat untuk menghasilkan low-grade heat yang artinya menggunakan panas atau energi dalam jumlah besar untuk menaikkan atau menurunkan temperatur ruangan hanya beberapa derajat bedanya dari temperatur sekitar. Banyak pusat pembangkit daya membuang panas limbah ke lingkungan sekitar sekitar dalam bentuk air panas, udara panas atau uap panas, banyak bangunan yang tidak terisolasi dengan baik yangmerupakan pemborosan karena panas dari luar bisa bocor ke dalam atau sebaliknya, banyak proses industri yang masih menggunakan lebih banyak energi dari yang dibutuhkan untuk membangkitkan daya operasional mereka. Kendaraan bermotor mengkonsumsi telahmengkonsumsi minyak dunia dalam jumlah besar, energi yang digunakan ini delain tidak efisien juma merupakan sumber pencemaran utama, saat ini penggunaan segala bentuk energiseperti dalam hal manusia menggunakan peralatan dengan pemakaian energi 
listrik, penggunaan bahan-bahan kimia yang tidak ramah lingkungan secara terus-menerus seperti parfum juga membantu meningkatnya pencemaran lingkungan.

Dikarenakan hal-hal tersebut diatas, bumi yang kita tinggali mengalami penurunansebagai contoh; tanah longsor, hal ini terjadi karena penebangan hutan yang sembarangan, dimana manusia tidak memperhatikan keseimbangan alam demi pemenuhan kebutuhan manusia tersebut. Erosi dan abrasi, merupakan proses pengikisan permukaan bumi oleh air dan air laut kerusakan ini oleh karena kegiatan alam, kerusakan lingkungan oleh karena kegiatan manusia berupa, yakni manusia memanfaatkan lingkungan tanpa disadari dapat merugikan lingkungan hidup, sebagai contoh; sampah, pembuangan sampah ini dapat membawa akibat berantai bagi pencemaran lingkungan berupa bau busuk yang menggannguorang sekitar, mempercepat terjangkitnya penyakit dan sumber penularan penyakit,tersumbatnya got-got dan aliran air yang berakibat banjir, dampark merusak kenyamanan dankeindahan kota. Terkurasnya flora dan faunam yakni flora dan fauna menjadi langka yang dapat dikhawatirkan akan terjadi kepunahan, pencemaran atau polusi karena pertambahan penduduk yang pesat dan tidak ditopang dengan daya dukung lingkungan serta tidak memperhatikan kaidah pemanfaatan sumber daya alam berwawasan lingkungan hidup pencemaran tersebut terdiri dari pencemaran air, pencemaran udara, pencemaran tanah dan pencemaran suara, tanah kritis karena produktivitas tanah sebagai tempat tumbuhnya tanaman menurun dan akhirnya tandus dan gersang, sehingga tanaman tidak dapat tumbuhlagi dan menghasilkan sesuai dengan harapan manusia. Penyimpangan iklim, yakni dimanakondisi iklim telah bergeser atau berubah, hal ini menimbulkan kecemasan dan ketakutan terutama petani, nelayan, pelayaran dan penerbangan. Ramalan cuaca tidak akurat, timbulnya angin topan, kekeringan dan curah hujan yang berlabihan. Hujan asam, yakni hujan yangairnya tercemar oleh polutan (debu dan asap) dan korosit, yang akibatnya benda-benda yangtimpa oleh hujan ini akan mengalami keropos dan berkarat, dan bila menimpa manusia akanterserang penyakit kulit dan pernapasan serta bila menimpa tanaman akan membuat pertumbuhannya kerdil dan menurunkan produktivitas tanaman tersebut. Hujan ini terjadi dinegara-negara industri maju. Penipisan ozon yang merupakan pelindung bumi dari panasnya sinar ultra violet dan infra merag dari matahari, terutama lapisan ozon di atmosfir, saat telah menipis bahkan berlubang di kedua kutub bumi, sehingga sinar infra merah dapat menembusatmosfir bumi dan tidak dapat dipantulkan kembali, yang akhirnya dapat menaikkan suhu bumi dan kondisi bumi semakin panas yang berakibat mencairnya secara besar-besaran es di kedua kutub bumi yang dapat meninggikan permukaan 
air laut dari waktu kewaktu. Hal ini dapat menenggelamkan kota-kota yang di daerah pantai atau daratan rendah pada beberapa puluh tahun mendatang yang dapat menyebabkan menipisnya ozon yaitukarena pemakaian gas CFC (Carbon Fluoro Oksida), Freon, Foem, Metanol sebagai imbas dari pemakaian AC dan alat pendingin lainnya seperti kulkas. Hal-hal tersbut diatas yang menjadi isu global, sehingga PBB mengeluarkan pedoman bagi perlindungan konsumen yang salah satu dari prinsipanya ialah pemerintah harus menetapkan prioritas tersendiri untuk perlindungan konsumen yang salah satunya menganai lingkungan. Perlindungan konsumen terhadap bahaya kesehatan dan keselamatan merekaialah yang dapat dilakukan pemerintah ditiap negara yaitu berupa promosi pola konsumsi berkelanjutan, yaitu melalui memberikan kemudahan akses informasi terhadap semuakonsumen yang ada di negaranya, aksesnya memadai dan memungkinkan mereka untuk dapat mambuat pilihan informasi sesuai dengang kebutuhan dan keinginan individu,memberikan pendidikan bagi konsumen termasuk pendidikan dampak lingkungan.

Pola berkelanjutan produksi dan konsumsi di negara-negara industri merupakan penyebab utama dari kerusakan lanjutan dari lingkungan global, maka semua negara harus mempromosikan pola konsumsi berkelanjutan, begitu juga dengan negaranegara berkembang harus berusaha untuk mencapai berkelanjutan pola konsumsi dalam proses pembangunan mareka. Kebijakan untuk mempromosikan konsumsi yang berkelanjutan harus dengan mempertimbangkan tujuan memberantas kemiskinan, memenuhi kebutuhan dasar manusia dari semua anggota masyarakat dan mengurangi ketidaksetaraan dalam dan antar negara. Pemerintah dalam setiap negara harus mampu menekan semua perusahaan, agar mematuhi hukum dan peraturan dari negara-negara dimana mereka melakukan bisnis, agar tidak terjadi praktek bisnis curang, dan setiap barang yang diproduksi merupakan barangyang ramah lingkungan dan aman bagi kesehatan manusia, serta barang tersebut diberikansimbol yang diketahui masyarakat internasional secara keseluruhan agar tidak terjadi kesalahan pengertian memaknai simbol. Para pengusaha juga harus sesuai dengan ketentuan sesuai standar internasional untuk perlindungan konsumen yang pihak berwenang yangkompeten dari negara yang bersangkutan telah sepakat.

Pemerintah harus menetapkan atau mendorong langkah yang tepat, termasuk mengenai sistem hukum, peraturan keselamatan, standar internasional atau nasional, guna memastikan bahwa produk tersebut aman dan baik untuk kesehatan konsumen dan aman untuk penggunaan mendatang (lingkungan). 
Pemerintah harus mengintensifkan upayanya untuk mencegah praktik-praktik yang merusak kepentingan ekonomi konsumen dengan memastikan bahwa produsen, ditributor dan lain-lain yang terlibat dalam penyediaan barang maupun jasa mematuhi hukum yang didirikan dan standar wajib, organisasi konsumen harus didorong untuk memantau praktek- praktek yang merugikan.

Pemerintah harus mempromosikan pengembangan dan penerapan standar ditingkat nasional dan internasional untuk keselamatan dan kualitas barang. Pemerintah harus mendorong semua pihak untuk berpartisipasi dalam aliran bebas akurat informasi tentang segala aspek dari produk konsumen. Serta akses konsumen terhadap informasi yang akurat tentang dampak lingkungan dari produk dan jasa harus didorong melalui sarana seperti profil produk, laporan lingkungan oleh industri, pusat informasi bagi konsumen, program eco-labeling sukarela dan transparan mengenai informasi produk.

Pemerintah dalam konteks nasional mereka sendiri, mendorong perumusan dan di implementasikan dengan bisnis, bekerjasama dengan oraganisasi konsumen. Pemerintah harus secara teratur meninjau undang-undang yang berkaitan. Di Indonesia sendiri telah memiliki Undang-Undang Nomor 8 Tahun 1999 tentang Perlindungan Konsumen, yangdibentuk guna pembangunan perekonomian nasional pada era globalisasi harus dapatmendukung tumbuhnya dunia usaha sehingga mampuu menghasilkan beraneka barang /jasayang memiliki kandungan terknologi yang dapat meningkatkan kesejahteraan masyarakat banyak dan sekaligus mendapatkan kepastian atas barang dan /jasa yang diperoleh dari perdagangan tanpa mengakibatkan kerugian konsumen.

\section{PENUTUP}

Peran masyarakat terhadap konsumsi berkelanjutan dengan upaya pengendalian kerusakan lingkungan yang dapat digunakan ialah mengurangi produksi gas karbon diokasida dengan mengurangi pemanfaatan bahan bakar dan produksigas rumah kaca yang lain, sebagai salah satu contoh penggunaan bahan bakar nabati.Menekan atau menghentikan penggundulan hutan, penghutanan kembali secara besar-besaran untuk menciptakan wilayah serapan gas CO2. Melakukan kerja sama internasional, menekan negara-negara penghasil gas rumah kaca terbesar seperti AS, Eropa dan sebagainya,mendorong PBB aktif melakukan tindakan pencegahan melalui perjanjian. Guna mencapai kehidupan berkelanjutan diperlukan strategi menuju tujuan tersebut,yaitu dengan cara memperhatikan prinsip kehidupan berkelanjutan sebagai berikut : memelihara/ menghormasi komunitas kehidupan, memperbaiki 
/meningkatkan mutukehidupan manusia, melestarikan keragaman bumi, menghindari pemborosan sumber daya alam, berusaha tidak melampaui kapasitas daya dukung bumi, mengubah gaya hidup orang per orang dan mendukung kreativitas masyarakat untuk memelihara lingkungannya sendiri, menyediakan kerangka kerja nasional untuk memadukan upaya pembangunan dan pelestarian, menciptakan kerja sama global.

\section{DAFTAR PUSTAKA}

Walhi, bumi wahan strategi menuju kehidupan yang berkelanjutan, Gramedia Pustaka UtamaJakarta, 1993

Soekanto, Soerjono 2009, Sosiologi Suatu Pengantar, Edisi Baru : Rajawali Pers.Jakarta

Sholahudin , Rohmat. 2013. Pengaruh Green Marketing Terhadap Keputusan Pembelian Produk Ades Jurusan PIPS Fakultas Keguruan dan Ilmu Pendidikan Universitas Sebelas Maret Tahun 2013. Skripsi. FKIP UNS

Nair, Chandran. 2013. Consumptionomics. Peran Asia Dalam Menciptakan Model Kapitalisme Baru. Red \& White Publishing. ISBN 978-979-1008-69-3

Wagner, Sigmund A. 1997. Understanding Green Consumer Behaviour: A qualitative cognitive approach. ISBN 0-203-75227-9 (Adobe eReader Format). Routledge.

The Business Role Focus Area. 2008. Business Role Focus Area's Sustainable Consumption \& Consumers. ISBN 978-3-940388-30-8. World Business Council for Sustainable Development. 